\title{
Wahania zwierciadła wód podziemnych pod wpływem wstrząsów górniczych w obszarze górniczym kopalni Rydultowy
}

\author{
Adam Frolik ${ }^{1}$, Sławomir Siwek ${ }^{1}$, Waldemar Kierepka ${ }^{1}$
}
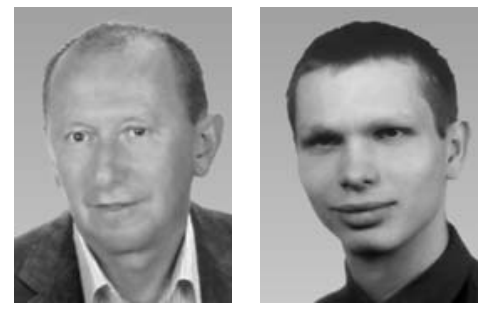

S. Siwek

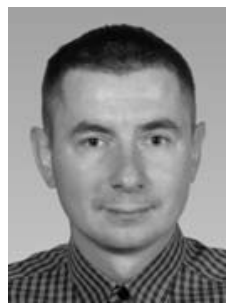

W. Kierepka

Groundwater level changes caused by influence of mining tremors - case study from the Rydultowy Mine Area (Poland). Prz. Geol., 68: 204-210; doi: $10.7306 . / 2020.8$

A b s t r a c t. In 2018, as part of the implementation of a European project: European Plate Observing System (EPOS-PL), a hydrological monitoring system was installed in a Rybnik test site. The system is configured to measure changes of groundwater level caused by seismic events which were induced by mining exploitation. The piezometers were drilled within an active mining area, in close vicinity to mining longwalls of the Rydultowy Coal Mine, an industrial partner in the project. The paper presents the state of knowledge on the phenomena of co-seismicity in hydrology, a description of installed measuring system, and the first hydrographs registered for mining tremors with a local magnitude from 2.7 to 3.1, which occurred up to $3 \mathrm{~km}$ away from the location of piezometers.

Keywords: groundwater level, coseismic, mining tremors

Na obszarze Górnośląskiego Zagłębia Węglowego na podstawie danych z Górnośląskiej Regionalnej Sieci Sejsmologicznej (grss.gig.eu), prowadzonej przez Główny Instytut Górnictwa, od kwietnia do października 2019 r. zostały zarejestrowane 54 wstrząsy bezpośrednio związane z prowadzeniem podziemnej eksploatacji złóż węgla kamiennego. Są to najsilniejsze wstrząsy górnicze o magnitudzie w przedziale 2,6-3,3, które odnotowano głównie w rejonie kopalń: Rydułtowy, Piast-Ziemowit, Budryk oraz Mysłowice-Wesoła.

W położonej w Rybnickim Okręgu Węglowym kopalni Rydułtowy zarejestrowano w tym okresie 13 wstrząsów o magnitudzie $>2,6$, a 4 z nich $>3,0$. Kopalnia prowadzi eksploatację w 3 pokładach węgla kamiennego na głębokości 900-1000 m p.p.t. Odkształcenia i zmiany naprężeń $\mathrm{w}$ górotworze, które towarzyszą prowadzonej z zawałem stropu eksploatacji, są przyczyną występowania wstrząsów sejsmicznych.

Celem pracy jest analiza zmian poziomu zwierciadła wód podziemnych, które występuja podczas wstrząsów powstałych pod wpływem prowadzonej eksploatacji górniczej mającej wpływ na górotwór, oraz przypuszczalną reaktywację uskoku Kolejowego w obszarze górniczym kopalni Rydułtowy. Prace te są prowadzone w ramach projektu EPOS-PL (Mutke i in., 2019).

W dotychczasowych obserwacjach zmian położenia zwierciadła wód podziemnych prowadzonych w kraju i za granicą sygnały ko-sejsmiczne, będące efektem silnych trzęsień Ziemi, były zwykle rejestrowane wraz ze zmianami obejmującymi jednocześnie inne czynniki silnie wpływające na wahania poziomu zwierciadła wody, takie jak: warunki atmosferyczne (ciśnienie), zasilanie bądź drenaż warstwy wodonośnej czy pływy litosferyczne (Frolik, Staszewski, 1997; Chen i in., 2010). Pływy litosferyczne wynikaja z wzajemnego oddziaływania grawitacyjnego najbliższych Ziemi obiektów układu słonecznego, powo- dując odkształcenia powierzchni skorupy Ziemi. Odkształcenia te mają charakter okresowych zmian w postaci fal pływowych o różnych częstotliwościach, od sekund do lat. Największe z nich powoduje oddziaływanie Słońca i Księżyca w okresach dobowym i półdobowym, co znajduje odzwierciedlenie w obserwacjach hydrogeologicznych.

Zjawiska ko-sejsmiczne są trudne do uchwycenia. Zazwyczaj przyjmowany interwał pomiarowy na poszczególnych stanowiskach był zbyt niskiej rozdzielczości, przez co sygnały te nie mogły być dotychczas skutecznie wyodrębniane. Mając na uwadze czas trwania wstrząsu górniczego (średnio $10 \mathrm{~s}$ ), w niniejszych badaniach zainstalowano nowe systemy pomiarowe, które umożliwiaja wprowadzenie odczytu zmian poziomu wody gruntowej w odstępach jednosekundowych.

\section{KO-SEJSMICZNE ZMIANY POZIOMU WÓD PODZIEMNYCH}

Zjawiska ko-sejsmiczne są zdarzeniami lub procesami występującymi w przyrodzie, bezpośrednio powiązanymi z aktywnością sejsmiczną (np. trzęsieniami Ziemi). Rozchodząca się od źródła fala sejsmiczna oddziałuje na wodę wypełniająca przestrzenie porowe $\mathrm{w}$ gruntach.

W wyniku dotychczasowych badań rozpoznano kilka różnych typów zmian poziomu wód podziemnych zachodzących pod wpływem bardzo silnych trzęsień Ziemi (He, Singh, 2019). Zarejestrowanie wstrząsu sejsmicznego w obrazie danych z przyrządów mierzących zmiany położenia zwierciadła wód podziemnych (w piezometrach) zależy od wielu czynników. Jednym z najważniejszych, decydującym o właściwościach rejestrowanych zmian jest odległość stanowiska pomiarowego od źródła wstrząsu, co zostało szczegółowo przedstawione w pracy Wanga i Chia (2008). Dla otworów piezometrycznych położonych w bezpośrednim sąsiedztwie źródła wstrząsu $(<25 \mathrm{~km})$ większość

\footnotetext{
${ }^{1}$ Zakład Geologii i Geofizyki, Główny Instytut Górnictwa w Katowicach, Plac Gwarków 1, 40-166 Katowice; a.frolik@gig.eu; s.siwek@gig.eu; w.kierepka@gig.eu
} 
udokumentowanych zmian poziomu zwierciadła wody podziemnej jest nagła, skokowa - wzrosty lub spadki (Wakita, 1975; Quilty, Roeloffs, 1997; Wang i in., 2001). Wówczas rejestracje zmian poziomu zwierciadła wody podziemnej pod względem fizycznym najlepiej tłumaczy zmiana ciśnienia porowego (na podstawie teorii poro-elastyczności) w warstwie wodonośnej - w strefach ich konsolidacji wskutek oddziaływania fali sejsmicznej dochodzi do wzrostu poziomu zwierciadła wody i jego obniżenia w strefie dezintegracji tych utworów (Wang i in., 2001). Dla dalej położonych stanowisk $(>25 \mathrm{~km})$ dokumentowane wahania poziomu zwierciadła wody podziemnej są łagodniejsze i przy silnych wstrząsach mogą się utrzymywać przez kilkanaście dni czy tygodni (Wang, Chia, 2008). Uważa się, że zmiany poziomu zwierciadła wody pod wpływem wstrząsu wynikają w tym przypadku ze wzrostu lub spadku przepuszczalności w obrębie warstwy wodonośnej wywołanego konsolidacją lub rozluźnieniem utworów przypowierzchniowych (Rojstaczer i in., 1995; Roeloffs, 1998; Brodsky i in., 2003). Zmiany poziomu zwierciadła wody mogą być również spowodowane zamykaniem i otwieraniem połączeń hydraulicznych $w$ formacji wodonośnej lub udrożnieniem spękań w skałach z wypełniającego je materiału poprzez przyspieszony wstrząsem przepływ wody. Dla największych odległości (>450 km) udokumentowano tylko przejściowe oscylacje poziomu wody (Wang, Chia, 2008).

Do zapisu zmian poziomu zwierciadła wody podziemnej w piezometrach stosowane są różne układy pomiarowe, przy czym obecnie najbardziej rozwinięte są zautomatyzowane stacje piezometryczne, które w wielu przypadkach działają jak stacje pogody, zapisując poza poziomem wody również jej temperaturę, $\mathrm{pH}$ i inne parametry, a także temperaturę powietrza atmosferycznego czy wartość ciśnienia atmosferycznego. W systemach tych jest możliwe dowolne próbkowanie pomiaru - od sekund do dni, miesięcy. Jednak ze względów praktycznych częstotliwość próbkowania ogranicza się zazwyczaj do jednego odczytu na minutę, godzinę lub dobę. Dalekie wstrząsy sejsmiczne, a właściwie trzęsienia ziemi, które są rejestrowane w obszarze GZW charakteryzują się czasem trwania od dziesiątek sekund do kilkunastu, a nawet kilkudziesięciu minut, dla dalekich i silnych trzęsień Ziemi. Określenie zmian położenia zwierciadła wód podziemnych dla niewielkich wstrzasów, do jakich należy zaliczyć te wywołane działalnością górniczą na terenie GZW, wymaga przeprowadzenia szeregu operacji matematycznych na gromadzonych zbiorach (Chen $\mathrm{i}$ in., 2010). Wynika to $\mathrm{z}$ faktu, że na poziom zwierciadła wód podziemnych ma wpływ wiele czynników, z których największe zmiany wywołują pływy litosferyczne, pływy oceaniczne, ciśnienie atmosferyczne, pobór wody i opady atmosferyczne (Bredehoeft, 1967; Van der Kamp, Gale 1983; Narasimhan i in., 1984; Roeloffs, 1998). Zastosowanie zapisu danych z piezometrów z częstotliwością $1 \mathrm{~Hz}$ zostało wykorzystane przez Lee i in. (2012), którzy wykazali dobrą korelację uzyskiwanych hydrogramów z sejsmogramami dotyczącymi trzęsienia Ziemi o sile $\mathrm{M}=7,9 \mathrm{w}$ skali Richtera. Według tych autorów obserwowane zmiany poziomu zwierciadła wód podziemnych w zakresie $0,2-2,3 \mathrm{~cm}$, dla piezometrów zainstalowanych w odległości $2000 \mathrm{~km}$ od epicentrum trzęsienia, dobrze korelowały się z przejściem wysokoenergetycznych fal Love'a i Rayligh'a.

\section{OBSZAR BADAŃ I WARUNKI GEOLOGICZNO-GÓRNICZE}

W ramach realizacji projektu EPOS-PL utworzono poligon doświadczalny $\mathrm{w}$ obszarze górniczym kopalni Rydułtowy, obecnie funkcjonującej jako jeden z ruchów w ramach połączonych kopalń Rybnickiego Okręgu Węglowego (ROW). Część eksploatacji złoża węgla kamiennego jest prowadzona przy północnej granicy obszaru górniczego kopalni, którą w naturalny sposób wyznacza przebiegający równoleżnikowo uskok Kolejowy zrzucający utwory karbonu o ok. $180 \mathrm{~m}$ na północ (ryc. 1).

Lokalizacja poligonu w rejonie uskoku Kolejowego wynika z faktu, iż w obszarze górniczym kopalni Marcel położonym na wschód od obszaru górniczego kopalni Rydułtowy prowadzona wcześniej eksploatacja w sąsiedztwie tego uskoku generowała bardzo silne wstrzasy sejsmiczne. Wstrząsy te spowodowały zarówno uszkodzenia podziemnej infrastruktury górniczej (tąpnięcia), jak i zabudowań na powierzchni, zwłaszcza położonych w pobliżu uskoku. W związku z podjęciem w podobnych warunkach geologiczno-górniczych eksploatacji w OG kopalni Rydułtowy bardzo prawdopodobne jest wystapienie analogicznych zjawisk.

Kopalnia Rydułtowy prowadzi eksploatację w trzech pokładach węgla kamiennego: 703/1, 706 i 713/1, w dwóch na głębokościach rzędu 900-1000 m p.p.t. Prowadzenie eksploatacji metodą zawałową prowadzi do dużych przeobrażeń w wyżej ległych warstwach skalnych. Efektem jest odkształcanie skał i zmiana układu naprężeń w górotworze oraz towarzyszące temu występowanie wstrząsów sejsmicznych zarówno w bezpośrednim sąsiedztwie ścian wydobywczych, jak i w obrębie strefy uskoku Kolejowego. Wstrzasy górnicze w obszarze górniczym kopalni Rydułtowy występują na głębokościach ok. 290-900 m p.p.t. oraz charakteryzują się energią zmieniająca się w bardzo szerokim zakresie od $10^{1}$ do $10^{7} \mathrm{~J}$, co odpowiada lokalnej magnitudzie w przedziale 1,0-3,5 wg skali Richtera (Mutke i in., 2018). Silniejsze wstrząsy górnicze charakteryzują się stosunkowo wysoką energią przy bardzo krótkim czasie trwania (średnio $10 \mathrm{~s}$ ), przez co w zasadzie nieznana jest wielkość oraz rodzaj zmian poziomu zwierciadła wód podziemnych pod ich wpływem. Zastosowanie bardzo gęstego próbkowania sygnału, wynoszącego $1 \mathrm{~Hz}$, powinno pozwolić na rejestrację wprost zjawiska ko-sejsmiczności poprzez eliminowanie innych czynników wpływających na położenie zwierciadła wody podziemnej w trakcie wstrząu czy bezpośrednio po zaistniałym wstrząsie.

W budowie geologicznej wytypowanego poligonu biora udział utwory karbonu produktywnego i czwartorzędu. W rejonie kopalni Rydułtowy karbon jest reprezentowany przez należące do serii paralicznej warstwy jaklowieckie i porębske (ryc. 2). Charakterystyczną cechą utworów paralicznych jest cykliczna (Buła, Żaba, 2005) budowa profilu składającego się ze skał klastycznych i fitogenicznych oraz występowanie osadów o wyraźnych wpływach morskich tworzących tzw. poziomy lub horyzonty morskie. Udział skał grubookruchowych w utworach paralicznych wynosi $20-50 \%$, na ogół są to piaskowce drobnoi średnioziarniste, rzadziej występują grubsze frakcje. Udział skał węglonośnych wynosi 3-4\%. Charakteryzują się dużą ilością warstw węgla, pokłady są jednak stosunkowo cienkie, raczej nie przekraczają 1,0-1,5 m grubości; niemniej 


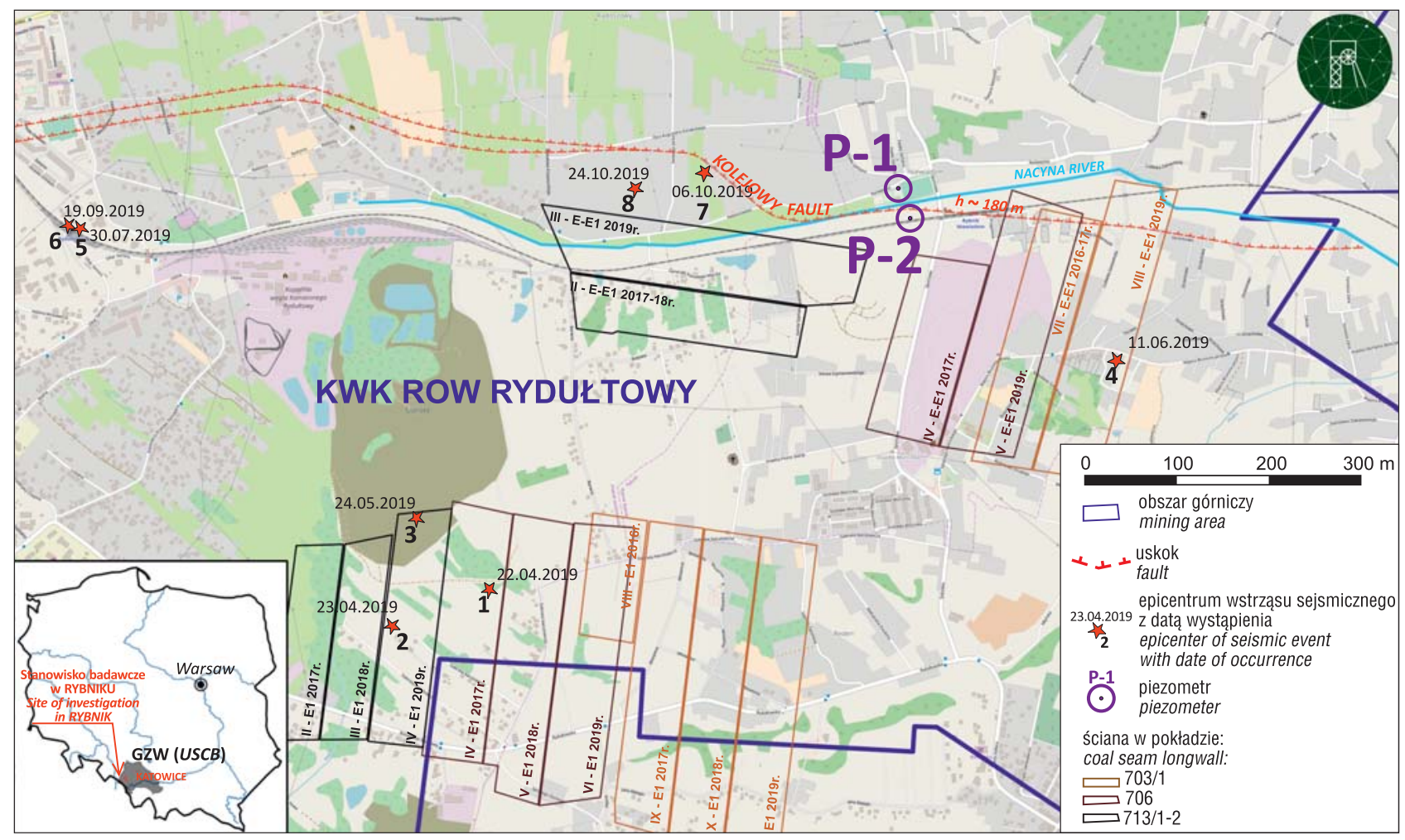

Ryc. 1. Lokalizacja stanowisk piezometrycznych oraz wytypowanych wstrząsów górniczych wraz z ich położeniem względem frontu eksploatacji kopalni Rydułtowy

Fig. 1. Location of piezometers and selected seismic events caused by mining exploitation with the projection of longwalls in coal seams of the Rydułtowy Mine in the study area

jednak wiele z nich jest eksploatowanych i ma duże znaczenie dla górnictwa. W stropie karbonu stwierdza się już występowanie osadów górnośląskiej serii piaskowcowej, reprezentowanych przez kompleks skał piaszczysto-zlepieńcowatych warstw siodłowych (z pokładami 505, 506 i 507) należących do namuru B. Leżą one na osadach paralicznych z przerwą stratygraficzną (Buła, Żaba, 2005). Odrębność litologiczno-facjalna górnośląskiej serii piaskowcowej wyraża się przewagą utworów gruboklastycznych nad drobnoklastycznymi oraz występowaniem grubych pokładów węgla. Osady gruboklastyczne (piaskowce) mogą osiągać nawet 90\% miąższości serii (Buła, Żaba, 2005).

Bezpośrednio na utworach karbonu cienką warstwą zalegają osady plejstocenu, które największą miąższość (do ok. $25 \mathrm{~m}$ ) osiagają w pradolinie rzeki Nacyny. Osady plejstocenu są wykształcone jako lodowcowe gliny i zalegające na nich wodnolodowcowe piaski, przeważnie średnie (Salomon, 2017). W samej dolinie Nacyny występuje zwykle kilkumetrowej miąższości warstwa piasków drobnych i średnich zaliczana do holocenu.

\section{SYSTEM POMIAROWY DO AUTOMATYCZNEGO MONITOROWANIA POZIOMU ZWIERCIADLA WODY PODZIEMNEJ}

Do obserwacji zmian zwierciadła wody podziemnej w północno-wschodniej części kopalni Rydułtowy zainstalowano dwa piezometry ujmujące pierwszy poziom wód podziemnych. Piezometry zamontowano w odległości $55 \mathrm{~m}$ na północ (P-1) i $45 \mathrm{~m}$ na południe (P-2) od uregulowanego koryta rzeki Nacyny. Z uwagi na morfologie powierzchni terenu, charakteryzującą się dużymi deniwelacjami, bliskość koryta rzeki była gwarantem nawiercenia poziomu wodonośnego. Dodatkowym kryterium lokalizacji piezometrów był przebieg uskoku Kolejowego (ryc. 1). I tak pierwszy z piezometrów (P-1) umiejscowiono na północnym, zrzuconym skrzydle uskoku, a drugi (P-2) w południowym, wyniesionym jego skrzydle (ryc. 2). Takie rozmieszczenie punktów pomiarowych ma na celu rozpoznanie wpływu uskoku przecinającego warstwy karbonu na przypowierzchniowe zmiany wód podziemnych występujących podczas wstrząsów indukowanych eksploatacją górniczą. Również długoterminowa obserwacja wody po obu skrzydłach dyslokacji ma na celu wyjaśnienie, czy prowadzone wydobycie węgla kamiennego może mieć wpływ na reaktywację uskoku. Obydwa piezometry, o głębokości $13 \mathrm{~m}$, zostały zaflirtowane w warstwie piasków plejstoceńskich (ryc. 3).

Piezometry zostały wyposażone w system pomiarowy do automatycznego monitorowania poziomu zwierciadła wody, składający się z czujnika poziomu wody oraz rejestratora danych (ryc. 3). Ceramiczny czujnik poziomu wody w obudowie ze stali nierdzewnej (Waterpilot FMX21 produkcji Endress+Hauser) mierzy ciśnienie hydrostatyczne słupa wody w zakresie 0-20 m i jest wyposażony w specjalny kabel z wbudowaną kapilarą do kompensacji ciśnienia atmosferycznego. Czujnik zapewnia dokładność pomiaru $\pm 0,25 \mathrm{~mm}$ i możliwość pracy w temperaturach od -5 do $60^{\circ} \mathrm{C}$ (specyfikacja techniczna producenta).

$\mathrm{Z}$ kolei zastosowany rejestrator danych z konwektorem analogowo-cyfrowym (produkcji PM Ecology Sp. z o.o.) posiada możliwość podłączania różnego typu sond w tym poprzez 4 kanały analogowe, pozwalające rejestrować impulsy z dużą częstotliwością (co najmniej $30 \mathrm{kHz}$ ). Rejestrator umożliwia programowanie zapisu danych w interwałach od 1 sekundy do 24 godzin lub więcej, a wbudowana 


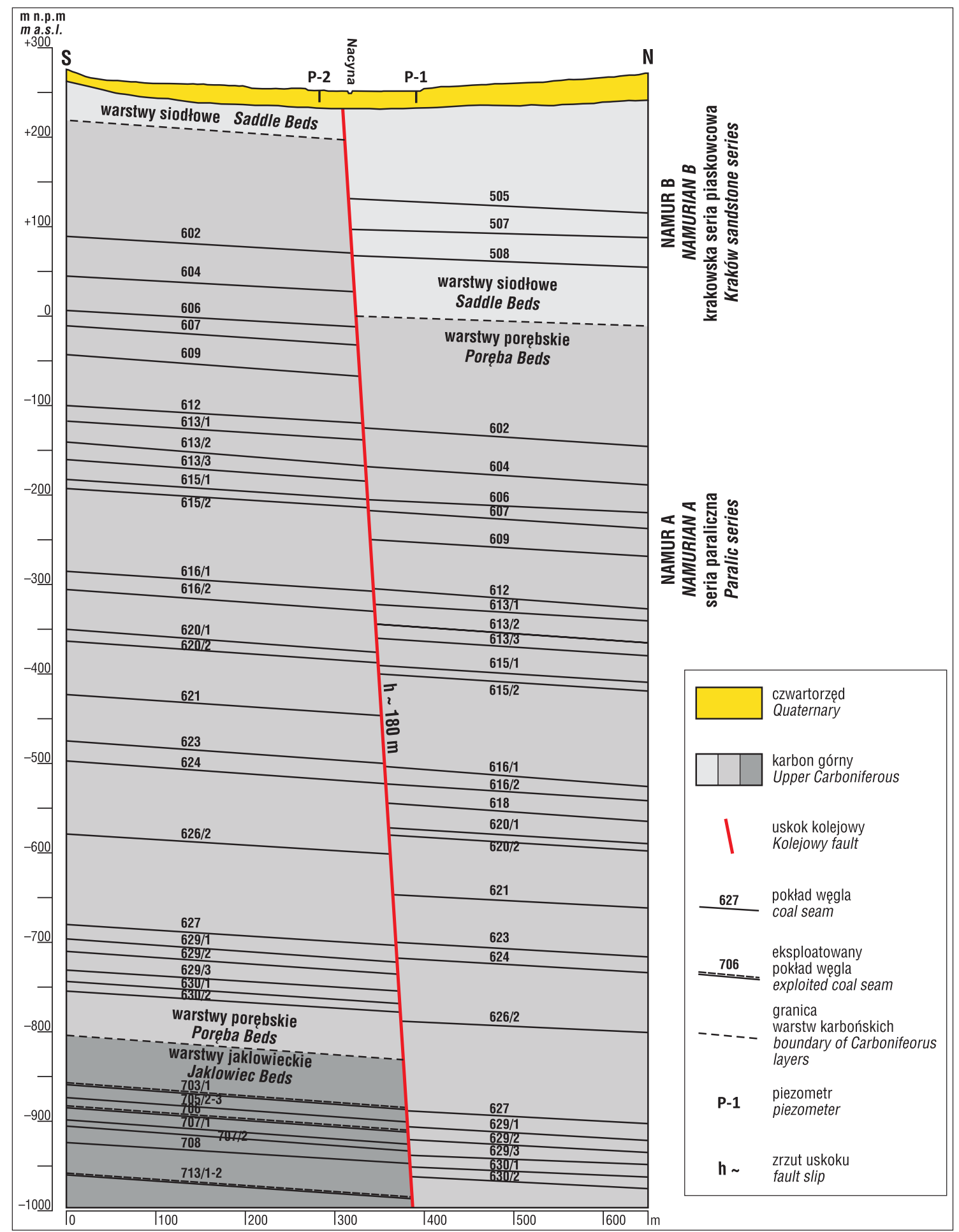

Ryc. 2. Przekrój geologiczny w rejonie lokalizacji piezometrów (na podstawie Górnika, 2001)

Fig. 2. Geological cross-section in the area of piezometer locations (based on Górnik, 2001)

pamięć pozwalająca zapisać co najmniej 600 tys. zmierzonych wartości. Urządzenie to pracuje w zakresie temperatur od $-20^{\circ} \mathrm{C}$ do $60^{\circ} \mathrm{C}$. Wyposażenie rejestratora w moduł GPRS umożliwia kontrolowanie i modyfikowanie działania rejestratora on-line oraz transmisję danych na docelowy serwer.

\section{WYNIKI REJESTRACJI WSTRZĄSÓW}

W wyniku prowadzonego z częstotliwością $1 \mathrm{~Hz}$ próbkowania i rejestrowania sygnału z układów pomiarowych piezometrów zainstalowanych w Rybniku możliwe jest wykreślenie bardzo szczegółowych hydrogramów, pozwalających na ocenę oddziaływania wstrząsów górniczych na poziom zwierciadła wód podziemnych, analogicznie do danych uzyskiwanych z sejsmometrów. Na rycinie 4 przedstawiono hydrogramy, na których zostały zarejestrowane wahania poziomu zwierciadła wód podziemnych bezpośrednio po 8 wybranych wstrząsach górniczych w kopalni Rydułtowy z okresu od 17 kwietnia (data rozpoczęcia rejestracji) do 31 października 2019 r.

Hydrogramy obrazują zmianę poziomu zwierciadła wód podziemnych w piezometrach P-1 i P-2 od momentu 


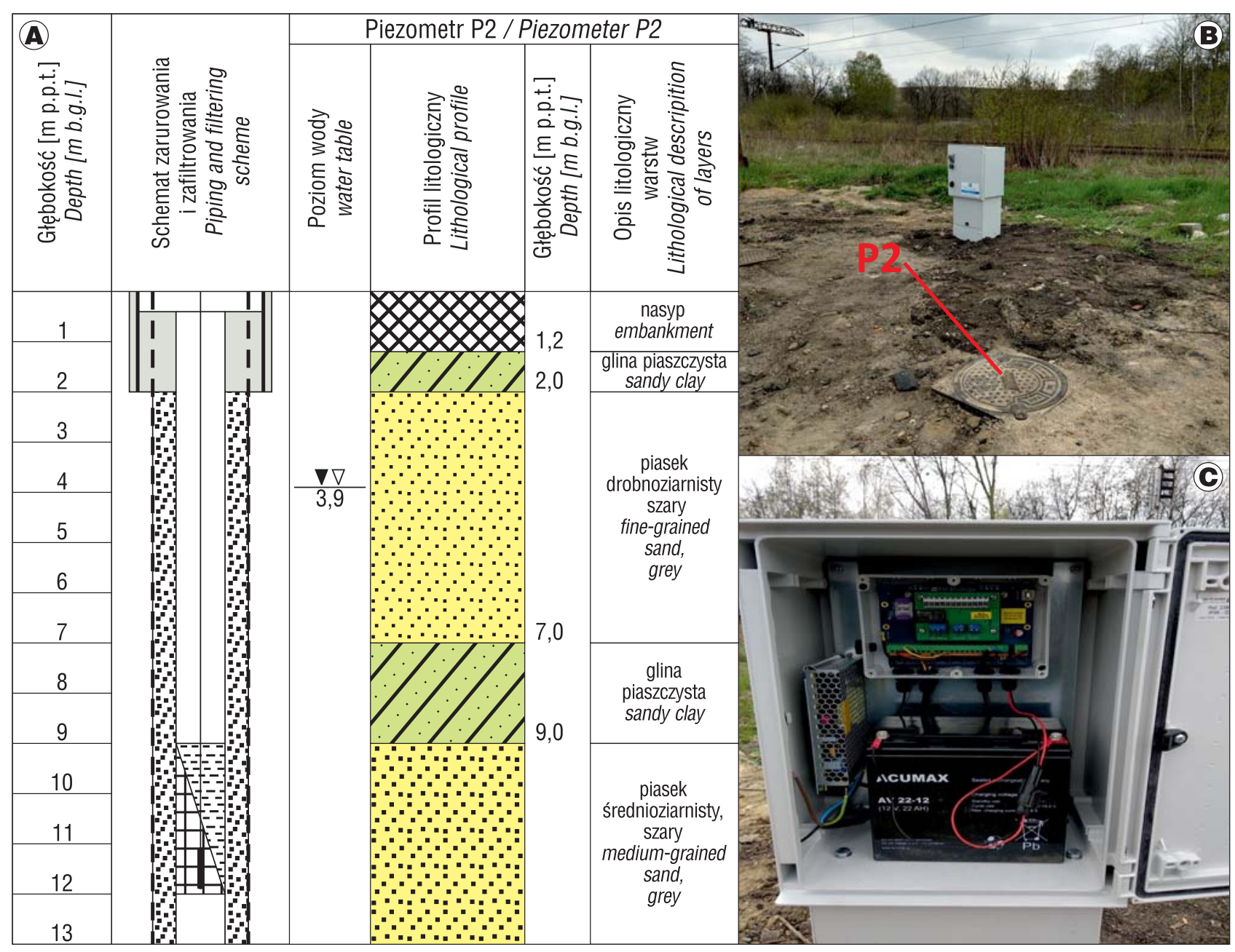

Ryc. 3. Profil geologiczny i lokalizacja stanowiska pomiarowego na przykładzie piezometru P-2. A-profil otworu, B - piezometr P-2 w terenie, $\mathbf{C}-$ rejestrator danych prod. PM Ecology. Fot. S. Siwek

Fig. 3. Geological-technical profile and location of piezometer P-2 in the study area. A-profile of piezometer, B - piezometer P-2 in field, C - PM Ecology data recorder. Photo by S. Siwek

wystąpienia wstrząsu górniczego do maksymalnie $1 \mathrm{~min}$. W tak niewielkim przedziale czasowym na poziom zwierciadła wody wpływa jedynie wstrząs górniczy. Wartość wychylenia jest obliczona dla każdego z piezometrów względem poziomu zwierciadła wody w momencie wystąpienia wstrząsu. Wyniki obserwacji jednoznacznie wskazują, że w obrazie zmian poziomu zwierciadła wód podziemnych rejestrowanych z częstotliwością $1 \mathrm{~Hz}$ występują efekty, które można wprost korelować ze wstrząsami sejsmicznymi. Mają one postać kilkusekundowych (5 do 10 sekund) wahań poziomu zwierciadła wody podziemnej.

Amplituda rejestrowanych zmian poziomu zwierciadła wody jest różna dla obydwu stanowisk: dla piezometru P-1 (krzywa niebieska) - zawiera się w przedziale 7,5-32,5 mm, a dla piezometru P-2 (krzywa czerwona) - 1,25-23,75 mm. Najwyższe amplitudy zmian położenia zwierciadła wody zostały zarejestrowane dla wstrząsu nr 8, który wystapił w odległości ok. 900 m od piezometrów. Na wszystkich wykresach widać, że układ pomiarowy w piezometrze P-1 lepiej reaguje na przechodzącą w warstwie wodonośnej falę sejsmiczną. Z uwagi na odległość pomiędzy piezometrami, wynoszącą $115 \mathrm{~m}$, różnice w odległościach do epicentrum wstrząsów zmieniają sie w zakresie 20-80 m. Przy uwzględnieniu odległości epicentrum wstrząsów do stanowisk pomiarowych dla wstrząsów oznaczonych symbolami od 1 do 4 jako pierwszy powinien zareagować układ pomiarowy piezometru P-2, a dla wstrząsów 5-8 piezometru P-1. Różnica czasu w zapisie sygnału na piezometrach nie powinna przekraczać kilku sekund.

Taką zgodność można zaobserwować w jednym przypadku, a mianowicie dla wstrząsu nr 4, który wystąił w odległości ok. 900 m na południowy zachód. Zarejestrowany został najpierw w bliżej położonym (o $80 \mathrm{~m}$ ) piezometrze P-2, a następnie w piezometrze P-1. Różnica czasu rejestracji pomiędzy stanowiskami wyniosła $\Delta \mathrm{t}_{4(\mathrm{P} 2-\mathrm{P} 1)}=7 \mathrm{~s}$. W przypadku wstrząsu $\mathrm{nr} 8$, który wystąpił w podobnej odległości, ok. 900 m, ale na zachód od piezometrów, nastąpiło odwrócenie kolejności rejestracji wstrząsu - jako pierwszy rejestruje położony o $42 \mathrm{~m}$ dalej piezometr P-2 zamiast piezometru P-1, przy czym różnica czasu rejestracji wstrząsu wynosi tylko $\Delta_{\mathrm{t} 8 \text { (P2-P1) }}=2 \mathrm{~s}$. Zaobserwowane zmiany są najprawdopodobniej związane z obecnością strefy uskoku Kolejowego.

Najbliżej piezometrów, w odległości ok. 670 m wystąpił wstrząs nr 7. Według danych z serwisu GIG miał on miejsce w obrębie strefy uskoku Kolejowego, co może być przyczyną dużej różnicy w czasie jego rejestracji w piezometrach $\Delta_{\mathrm{t} 7 \text { (P2-P1) }}=27 \mathrm{~s}$ oraz niskiej amplitudy zmiany poziomu zwierciadła wody w piezometrze P-2.

Dla wstrząsów 1, 2 i 3, które wystąpiły w podobnej odległości, ok. $2 \mathrm{~km}$ na południowy zachód od piezometrów, uwidacznia się brak zależności czasu rejestracji tych 


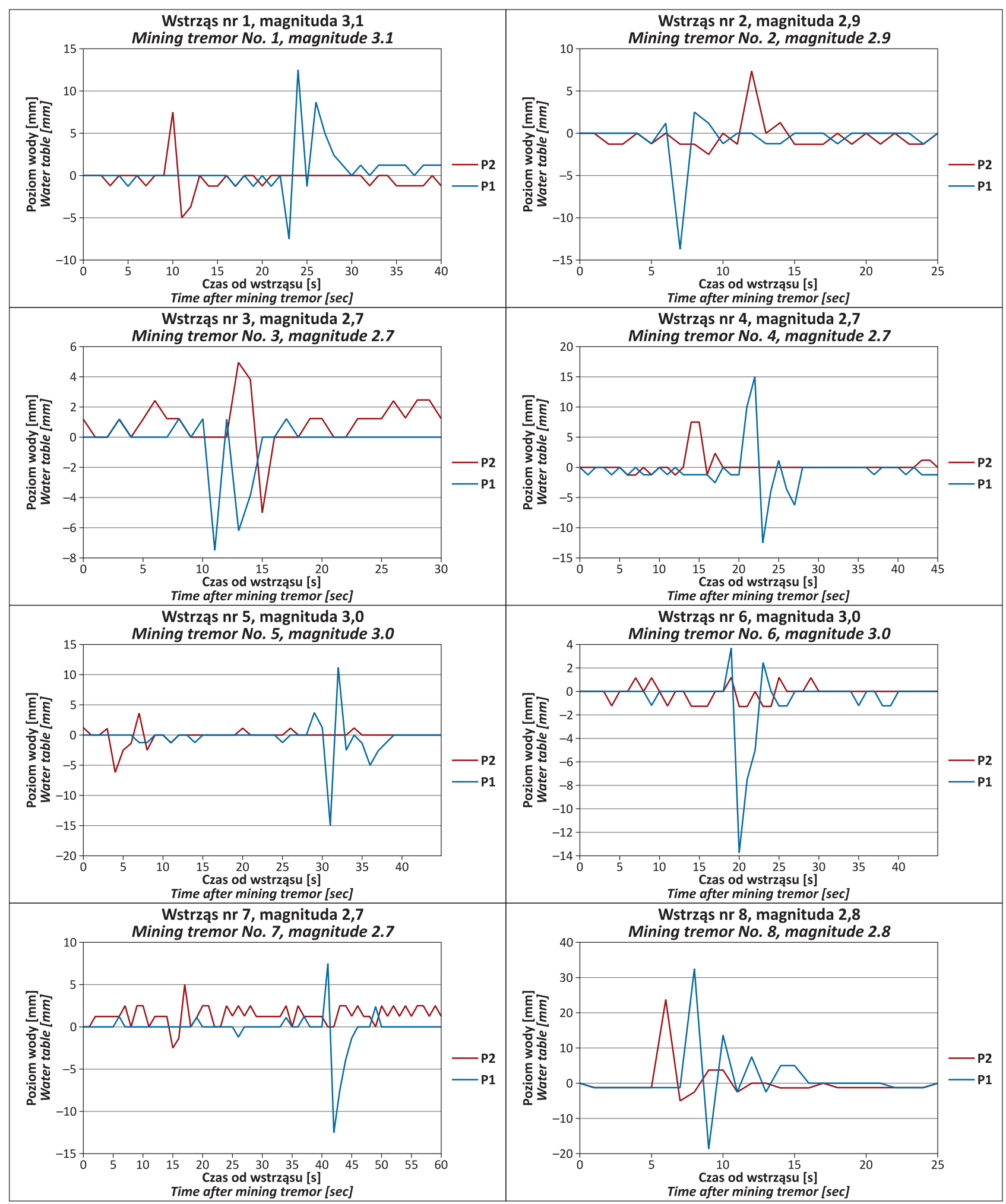

Ryc. 4. Zmiany poziomu zwierciadła wód podziemnych po wybranych wstrząsach górniczych

Fig. 4. Groundwater level changes observed after selected mining tremors caused by mining exploitation

wstrząsów od ich odległości od piezometrów. Następuje również odwrócenie kolejności rejestracji w przypadku drugiego i trzeciego wstrząsu, jako pierwszy reaguje dalej położony piezometr P-1.

Podobnie dla wstrząsów 5 i 6, które wystąpiły w odległości ok. $3 \mathrm{~km}$ na zachód. Układ pomiarowy piezometru P-2 w przypadku wstrząsu nr 6 najprawdopodobniej nie zarejestrował zmian położenia zwierciadła, a nr 5 - zarejestrował w niewielkim stopniu.
Obserwowane zaburzenia czasu przebiegu oraz amplitudy rejestrowanych przy pomocy układów pomiarowych piezometrów wahań zwierciadła wody podziemnej wskutek oddziaływania wstrząsów górniczych, mogą być związane zarówno z obecnością strefy uskoku Kolejowego, jak również $\mathrm{z}$ różnic $\mathrm{w}$ budowie geologicznej eksploatowanych fragmentów złoża czy też lokalnych warunków hydrogeologicznych w miejscu zabudowy piezometrów. 


\section{PODSUMOWANIE}

Jak wykazują wstępne wyniki obserwacji, pomiary prowadzone z dużą częstotliwością $(1 \mathrm{~Hz})$, za pomocą bardzo precyzyjnych czujników $(0,25 \mathrm{~mm})$, pozwalają na uchwycenie ko-sejsmicznych zmian poziomu zwierciadła wód podziemnych. Zastosowanie gęstego opróbowania sygnału umożliwia wyeliminowanie wszelkich wpływy, które wynikaja ze zmian warunków hydrometeorologicznych czy pływów ziemskich i wprost rejestrować zjawiska ko-sejsmiczne.

Zarejestrowane na stanowiskach piezometrycznych zjawiska ko-sejsmiczne, podobnie jak zapisy danych z sejsmometrów, charakteryzują się kilkusekundowym czasem trwania. Przedstawione hydrogramy wskazuja, iż uskok Kolejowy stanowi ważny element w propagacji fali sejsmicznej w badanej części złoża kopalni Rydułtowy.

Badanie zmian poziomu zwierciadła wody podziemnej jest ważnym czynnikiem oceny wpływu wstrząsów górniczych na warunki gruntowo-wodne podłoża budowli na terenach górniczych. Dlatego też w projekcie EPOS-PL przewidziano dodatkowo odwiercenie w bliskim sąsiedztwie każdego z piezometrów dwóch kolejnych otworów, w których będą zainstalowane sonda geotechniczna oraz sejsmologiczna. Z dodatkowych czujników zostaną uzyskane dane dotyczące zmian naprężenia $\mathrm{w}$ gruncie oraz parametry wstrząsu górniczego bezpośrednio w miejscu rejestracji zmian zwierciadła wód podziemnych.

Niniejsza praca została zrealizowana w ramach projektu pt. System Obserwacji Plyty Europejskiej EPOS-PL, finansowanego w ramach działania 4.2 Programu Inteligentny Rozwój, współfinansowanego przez Unię Europejską z Europejskiego Funduszu Rozwoju Regionalnego (ERDF). Nr umowy projektu: POIR.04.02.00-14-A003/16-00. Autorzy pragną podziękować Recenzentom za cenne uwagi i wskazówki dotyczące niniejszego artykułu.

\section{LITERATURA}

BREDEHOEFT J.D. 1967 - Response of well-aquifer systems to earth tides. J. Geophys. Res., 72 (12): 3075-3087.

BRODSKY E., ROELOFFS, WOODCOCK D., GALL I., MANGA M. 2003 - A mechanism for sustained groundwater pressure changes induced by distant earthquakes. J. Geophys. Res., 108 (B8), 2390, doi: $10.1029 / 2002 J B 002321$.

BUŁA Z., ŻABA J. 2005 - Pozycja tektoniczna Górnośląskiego Zagłębia Węglowego na tle prekambryjskiego i dolnopaleozoicznego podłoża [W:] Jureczka J., Buła Z., Żaba J. (red.), LXXVI Zjazd Naukowy PTG, „Geologia i zagadnienia ochrony środowiska w regionie górnośląskim”.
Rudy k. Rybnika, 14-16 września 2005 r. Mat. konf., Państw. Inst. Geol., Polskie Tow. Geol., Warszawa: 14-42.

CHEN C.H., WANG C.H., LIU J.Y., LIU C., LIANG W.T., YEN H.Y., YEH Y.H, CHIA Y.P., WANG Y. 2010 - Identification of earthquake signals from groundwater level records using the HHT method. Geophys. J. Inter., 180 (3): 1231-124.

FROLIK A., STASZEWSKI B. 1997 - Prognozowanie zmian warunków wodnogruntowych i ich wpływ na położenie obiektów budowlanych. Prace naukowe Głównego Instytutu Górnictwa. Seria: Konferencje No. 20. Ochrona powierzchni i obiektów budowlanych przed szkodami górniczymi, Katowice: 97-110.

GÓRNIK M. 2001 - Dokumentacja określajaca warunki hydrogeologiczne złoża Kopalni Węgla Kamiennego „Rydułtowy”. Katowickie Przedsiębiorstwo Geologiczne, Katowice. Praca niepublikowana.

HE A., SINGH R.P. 2019 - Groundwater level response to the Wnechuan earthquake of May 2008. Geomatics, Natural Hazards and Risk, 10 (1): 336-352, doi:10.1080/19475705.2018.1523236.

LEE T.P., CHIA Y., YANG H.Y., LIU C.Y., CIU Y.C. 2012 - Groundwater level changes in Taiwan caused by the Wenchuan Earthquake on 12 May 2008. Pure and Applied Geophysics, 169: 1947-1962

MUTKE G., BARAŃSKI A., CHODACKI J., DUBIŃSKI J., KOWAL T., LURKA A., MUSZYŃSKI L., STEC K. 2018 - Zasady stosowania Górniczej Skali Intensywności Sejsmicznej GSIS-2017 do prognozy skutków oddziaływania wstrząsów indukowanych eksploatacją na obiekty budowlane oraz klasyfikacji ich odporności dynamicznej. Instrukcja nr 23 Głównego Instytutu Górnictwa.

MUTKE G., KOTYRBA A., LURKA A., OLSZEWSKA D., DYKOWSKI P., BORKOWSKI A., ARASZKIEWICZ A., BARAŃSKI A. 2019 - Upper Silesian Geophysical Observation System - a unit of the EPOS project. J. Sustainable Mining, 18 (4): 198-207, doi: 10.10.16/ j.jsm.2019.07.005.

NARASIMHAN T.N., KANEHIRO B.Y., WITHERSPOON P.A. 1984 Interpretation of earth tide responses of three deep, confined aquifers. J. Geophys. Res., 89 (B3): 1913-1924.

QUILTY E., ROELOFFS E. 1997 - Water level changes in response to the December 20, 1994, M4.7 earthquake near Parkfield, California. Bull. Seismolog. Soc. America, 87: 310-317.

ROELOFFS E. 1998 - Persistent water level changes in a well near Parkfield, California, due to local and distant earthquakes. J. Geophys. Res., 103: 869-889.

ROJSTACZER S., WOLF S., MICHEL R. 1995 - Permeability enhancement in the shallow crust as a cause of earthquake-induced hydrological changes. Nature, 373: 237-239.

SALOMON T. 2017 - Elsterian ice sheet dynamics at a topographically varied area (southern part of the Racibórz - Oświęcim Basin and its vinicity, S Poland). Geol. Quart., 61 (2): 465-479.

WAKITA H. 1975 - Water wells as possible indicators of tectonic strain. Science, 189: 553-555.

WANG C.Y., CHENG L. H., CHIN C. V., YU 2001 S. B., Coseismic hydrologic response of an alluvial fan to the 1999 Chi-Chi earthquake, Taiwan. Geology, 29: 831-834.

WANG C.Y., CHIA Y. 2008 - Mechanism of water level changes during earthquakes: Near field versus intermediate field. Geophys. Res. Let., 35 (12), doi:10.1029/2008GL034227.

VAN DER KAMP G., GALE J.E. 1983 - Theory of earth tide and barometric effects in porous formations with compressible grains. Water Resources Res., 19 (2): 538-544,

Praca wpłynęła do redakcji 4.12.2019 r. Akceptowano do druku 21.01.2020 r. 